\title{
Increasing coverage of reproductive health issues in the Indonesian print media
}

Wanda Firmansyah

Sahar Hegazi

Siti Rokhmawati Darwisyah

Lila Amaliah

Follow this and additional works at: https://knowledgecommons.popcouncil.org/departments_sbsr-rh

Part of the Demography, Population, and Ecology Commons, International Public Health Commons, Public Health Education and Promotion Commons, and the Women's Health Commons How does access to this work benefit you? Let us know!

\section{Recommended Citation}

Firmansyah, Wanda, Sahar Hegazi, Siti Rokhmawati Darwisyah, and Lila Amaliah. 2001. "Increasing coverage of reproductive health issues in the Indonesian print media," FRONTIERS Final Report. Jakarta: Population Council. 


\title{
Increasing Coverage of Reproductive Health Issues in the Indonesian Print Media
}

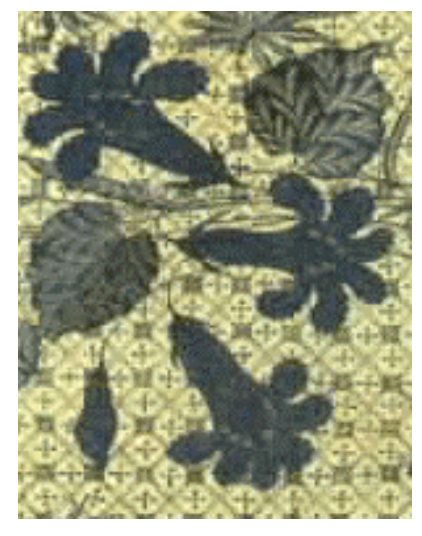

\author{
Wanda Firmansyah, SIP \\ Sahar Hegazi, MA \\ Siti Rokhmawati Darwisyah, SKM \\ Lila Amaliah, SKM
}

March 2001

The project, "Media Information Dissemination to Increase Coverage of Critical Health Issues and to Promote Appropriate Health Behavior and Services," was conducted from May 1, 1999 to October 31, 2000. This project was funded by the U.S. AGENCY FOR INTERNATIONAL DEVELOPMENT (USAID) under the terms of Cooperative Agreement Number HRN-A-00-98-00012-00 and Subproject Number 5801-13011-452. The opinions expressed herein are those of the authors and do not necessarily reflect the view of USAID. 


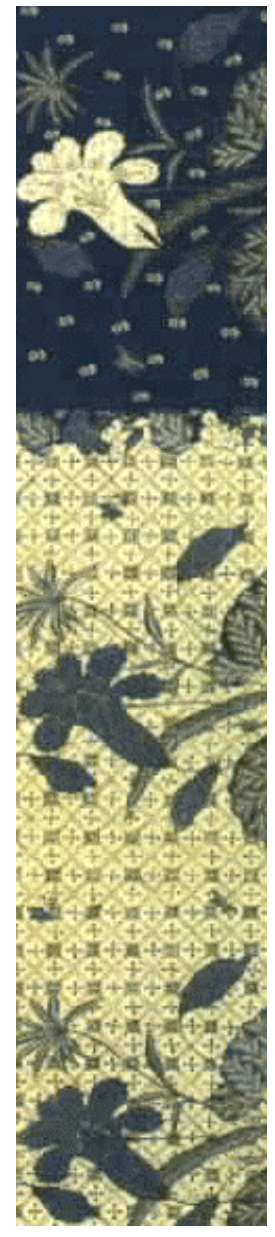

SUMMARY

The economic and political crises underlying the reformasi (reform)

movement in Indonesia presented tremendous challenges for safeguarding the health and welfare of Indonesian women and children. The overnight liberalization of the press created new opportunities for influencing public debate and informing public opinion on reproductive health issues. Yet few journalists have had experience in covering women's health or possess a network of informed sources. The FRONTIERS project stepped into this dynamic process and seized opportunities for disseminating the results of contemporary research on reproductive health.

This project had three main objectives: (1) to increase print media coverage of critical reproductive health issues by enhancing journalists' role as responsible communication agents; (2) to contribute to public debate on emerging reproductive health issues in order to influence policy development and guide program management; and (3) to increase public awareness of key health issues, with a particular focus on crisis-related reproductive health needs.

The project implemented several activities to produce these results. A core network of 22 journalists representing both national and regional media was selected to participate in the project. In September 1999 the project staff organized a roundtable dialogue between health editors from the print media and experts in reproductive health. A training workshop for journalists was held in January 2000 to increase their understanding of reproductive health and to upgrade their ability to write articles using research findings. Training modules utilized multiple approaches, including role-playing, simulation, testimony, and field visits, to investigate different techniques for gathering information and to practice writing short articles on interesting topics.

Following the training workshop, a series of five media forum discussions were organized to explore important reproductive health issues in depth. In general, two speakers led each media forum: a program coordinator and a researcher. Representatives from the State Ministry for Women's Empowerment and other senior health journalists were invited to participate in the forums. Press briefing kits (which included fact sheets, research summaries and parts of translated literature) were provided to each journalist during the media forum discussions and were distributed to other journalists afterwards. In addition, seven press releases on a range of reproductive health topics were distributed during the media forum discussions. 
During each of the media forums, participants were informed that all the articles on reproductive health published between October 1999 and August 2000 would be nominated for a writing competition. A final media event was organized at the end of the project at which winners were announced for the best and most comprehensive article. Another award was given to the publishing house that devoted the largest space to reproductive health articles.

The impact of this project was assessed in terms of the gains in journalists' technical knowledge about the themes of the media forums and the number and quality of their published articles. Several data collection tools were used to measure these indicators. First, a media monitoring system was developed that scanned daily newspapers and magazines and coded all articles with a reproductive health topic according to pre-set criteria. Second, preand post-tests of the participants' knowledge were conducted at every media forum discussion. In addition, project staff logged the number of contacts made by journalists to the Population Council office requesting reproductive health information.

Based on the results of the process and media monitoring evaluations, the 18-month media information dissemination project had a positive impact on the coverage of reproductive health in the Indonesian print media. Between September 1999 and September 2000, 7 percent of all reproductive health articles published in the Indonesian press resulted from the project intervention (120 articles out of 1,836 articles). Safe motherhood was the most frequently covered issue in both newspapers and magazines (28 articles), followed by RTIs/STIs (12 articles) and violence against women (11 articles). News articles were the dominant type of story, followed by features. During the 13-month media relations activities, 6 percent of all newspaper articles and 8 percent of all magazine articles on reproductive health in the Indonesian press resulted from project activities ( 82 articles out of 1,473 newspaper articles and 26 out of 344 magazine articles). Large circulation newspapers and magazines (averaging 250,000 for newspapers and 90,000 for magazines) were more likely to use the project materials.

The articles produced by the journalists who took part in the media forums or who received the press briefing kits reflected the use of diverse sources of information and a selection of highly relevant findings to support the articles' topics. Many of the journalists used the information and the research data included in the press briefing kits directly in their articles. There were some shortcomings, however. Some of the story titles were misleading, and articles written by journalists who received the briefing kits but who had not participated 
in the media forum workshops were not comprehensive and were sometimes inaccurate. This finding indicates the importance of organizing training programs for journalists.

This project demonstrated that media could be effectively utilized to extend the reach of research findings and to initiate public debate regarding important reproductive health issues. Based on this project, the authors recommend that public and private health agencies: (1) include the results of a larger number of research studies in the process of developing press-briefing kits and media background informational materials, especially those with recent data on reproductive health issues; (2) increase the number of reproductive health training programs for journalists; (3) motivate senior editors to devote more space to health issues; and (4) expand the media network to include journalists from radio and television. 


\section{TABLE OF CONTENTS}

Summary

Table of Contents . V

List of Tables and Figures................................................................................... vi

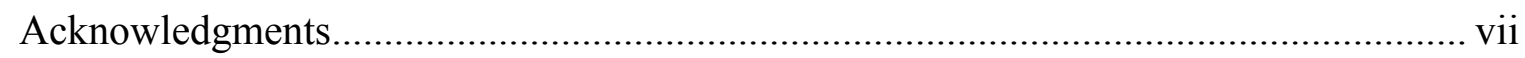

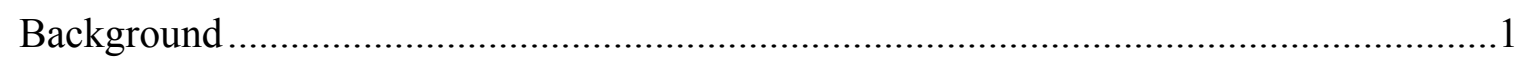

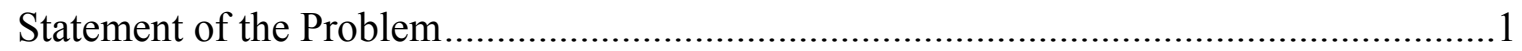

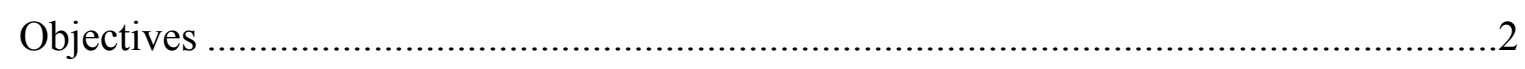

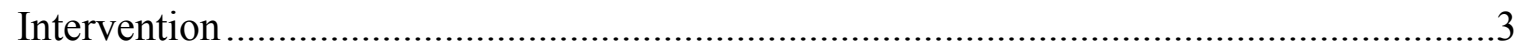

I. Building an Informed Network of Journalists .................................................

II. Media Forum Discussions ...........................................................................4

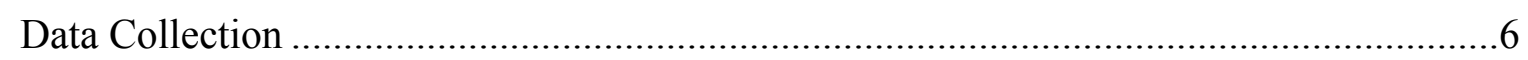

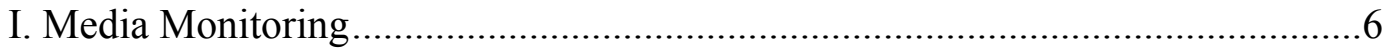

II. Journalists Contact Sheet ................................................................... 9

III. Pre- and Post-test Evaluation Sheet ................................................................ 9

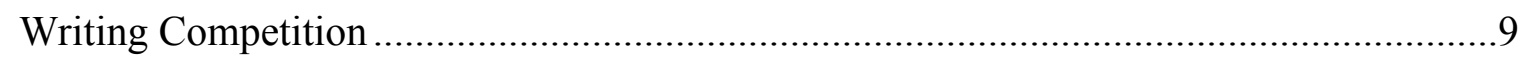

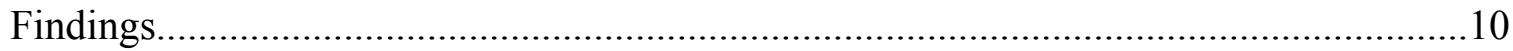

I. Impact of Training on Journalists' Reproductive Health Knowledge ................10

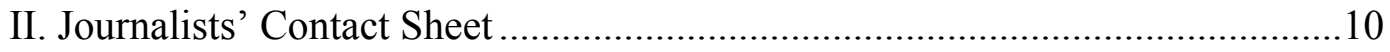

III. Assessment of Media Coverage of Reproductive Health ...............................10

IV. Impact of Reproductive Health Press Coverage on Program Management ....15

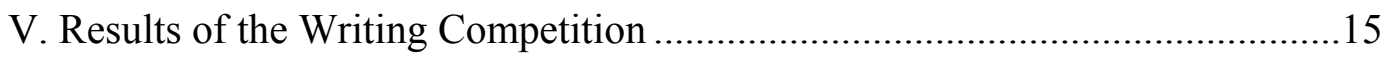

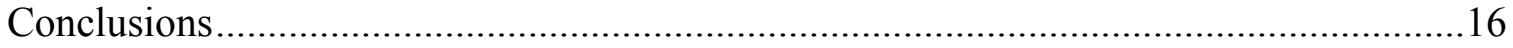

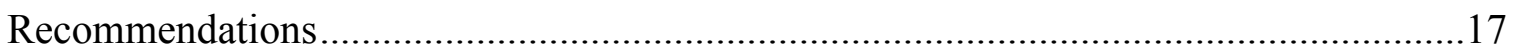




\section{LIST OF TABLES AND FIGURES}

Table 1: News Outlets Selected for Monitoring 7

Figure 1: Total Number of Reproductive Health and Project-related Articles in Newspapers, Magazines, Tabloids and Internet (September 1999 - September 2000).... 10

Figure 2: Percentage and Type of Total Reproductive Health Articles Published in Sample Newspapers (September 1999 - September 2000)....

Figure 3: Total Number of Reproductive Health and Project-related Articles in Sample Newspapers (September 1999 - September 2000).

Figure 4: Total Number of Reproductive Health and Project-related Articles of Different Topics in Sample Newspapers (September 1999 - September 2000).

Figure 5: Total Number of Reproductive Health and Project-related Articles in Sample Newspapers (September 1999 - September 2000).

Figure 6: Total Number of Reproductive Health and Project-related Articles in Sample Magazines and Tabloids (September 1999 - September 2000)

Figure 7: Percentage and Type of Total Reproductive Health Articles Published in Magazines and Tabloids (September 1999 - September 2000)

Figure 8: Total Number of Reproductive Health and Project-related Articles in Sample Magazines and Tabloids (September 1999 - September 2000)

Figure 9: Total Number of Reproductive Health and Project-related Articles by Primary Topics in Magazines and Tabloids (September 1999 - September 2000) 


\section{ACKNOWLEDGMENTS}

This report is the culmination of one-year of dissemination and advocacy work

by the media project staff of Frontiers in Reproductive Health in the Population

Council/Indonesia office. Project staff expresses their sincere appreciation to all those individuals and organizations who have worked on the media information dissemination project and contributed to the enhanced dissemination of reproductive health information in Indonesia.

Special thanks go to the United States Agency for International Development/Jakarta for prioritizing the need for project assistance and providing financial support to this project. We also thank the Ministry for Women's Empowerment in Indonesia. In particular, thanks are extended to Ms. Rieny Hardjono, First Assistant for Family Planning, Ministry of Women's Empowerment, for her guidance as the project's advisor.

We also would like to thank the speakers who kindly participated in the media forum discussions and workshop. Special thanks are extended to Dr. Slamet Riyadi, Dr. Meiwita Budiharsana, Professor Saparinah Sadli, Dr. Biran Affandi, SpOG, Dr. Purnianti Mangunsong, Dr. Sri Djuarini, Dr. Siti Nurul Qomariyah, Dr. Sjaiful Fahmi Daily, Dr. Wresti Wirabuana, Dr. Terrence Hall, Dr. Attashendartini Habsjah, Dr. Ciptasari Prabawanti, Dr. Ninuk Widyantoro, Dr. Raditya Wratsangka, and Catharina Wahyurini together with her dedicated staff from PKBI Jakarta.

Finally, the authors are grateful to colleagues of the Frontiers in Reproductive Health and the Population Council/Jakarta, who provided continuing support and insights. Particular thanks are extended to Dale Huntington, FRONTIERS Associate Director for Asia and the Near East, Sahar Hegazi, FRONTIERS Regional Communication Officer for Asia and Near East, Cynthia Green, Program Associate for Policy Communication and Dissemination, and Anjali Nayyar, South East Asia Regional Communication Officer. The authors also are grateful to Saroj Pachauri, Regional Director for South East Asia, and Budi Utomo, Country Director of Population Council/Jakarta. 


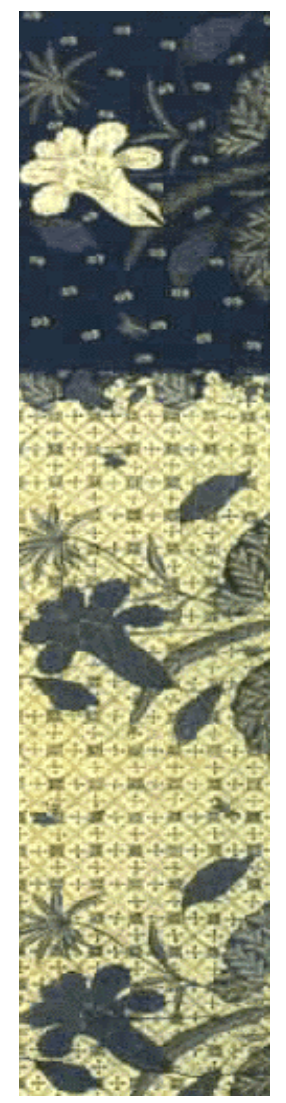

\section{BACKGROUND}

The confluence of events in Indonesia over the past two years, including the economic and political crises and the reformasi (reform) movement, presents tremendous challenges as well as opportunities for promoting the health and welfare of Indonesia's most vulnerable groups. The most serious impacts of the prolonged economic crisis on Indonesia's women and children predictably include the following negative effects: limited access to and use of health services; inadequate diet resulting in nutritional deficiencies (including anemia); and decreased compliance in contraceptive use due to the increase in cost and lack of commodities. Furthermore, the combination of high unemployment and women's low socio-economic status is associated with increased physical and sexual abuse and mental depression. Among married women of reproductive age a decline in the use of contraceptives will undoubtedly lead to an increase in unplanned and unwanted pregnancies, higher birth rates and increased abortion-related maternal morbidity and mortality.

Less predictable in its outcomes but a far more optimistic result of the political crisis in Indonesia is the overnight liberalization of the media following the establishment of the "New Reform Era." The surge in freedom of the press offers a vehicle for providing the public with critical information about crisis-driven problems, resources and services. The media can be used to inform people about social safety net resources available in their area and how to access them. It can increase awareness of escalations in family violence and provide information for victims about where to get help. It can also be used as a channel to disseminate contemporary research results (such as those stemming from the adolescent reproductive health survey) in order to influence public debate about critical health issues.

Following years of restrictions on their activities and suppression of facts, journalists in Indonesia are scrambling to keep up with the newly created opportunities. Aware of the complexities involved in responding to the crisis situation, USAID places high priority on building the capacity of journalists to act as responsible communication agents.

\section{STATEMENT OF THE PROBLEM}

The media, which has traditionally been male dominated, often neglects issues that dramatically affect women's lives. As the crisis ensues it is becoming increasingly evident that media coverage of health issues is essential to the effort aimed at protecting 
Indonesia's most vulnerable women and children. Yet in general, media professionals possess a limited background in this substantive area and need a reliable source of information on reproductive health issues.

The Media Information Dissemination Project was designed to provide recent and accurate reproductive health operations research and other crisis-related scientific findings in a manner suitable for immediate use by a variety of local print media journalists. The implementation of this project was closely coordinated with the following national and international agencies to ensure that the key issues are addressed in a manner that reflects ongoing program priorities, based on the most recent research findings.

- State Ministry for Women's Empowerment

- National Family Planning Coordinating Board, Ministry of Health (BKKBN)

- Yogya Institute of Research, Education, and Publications (LP3Y)

- Indonesian Planned Parenthood Association (PKBI)

- Mitra Perempuan

- Atmajaya Research Center

- Center for Health Research, University of Indonesia

- USAID

- Ford Foundation

- UNFPA

- PATH

- The Futures Group

\section{OBJECTIVES}

This project supports the government's social safety net initiative by increasing media coverage and public awareness of health needs related to the economic crisis. The long-term objective of the project is to contribute to national efforts responding to the complex dimensions of the economic crisis and its impact on the health of Indonesia's most vulnerable women and children. The project has the following short-term objectives:

1. To increase print media coverage of critical health issues by enhancing journalists' role as responsible information and communication agents, including as a conduit for public information dissemination and feedback related to health resources and information.

2. To contribute to public debate on emerging reproductive health issues in order to influence policy development and guide program management.

3. To increase public awareness of key health issues, with a particular focus on crisisrelated reproductive health needs at the primary health care level and promotion of appropriate health behaviors and services. 


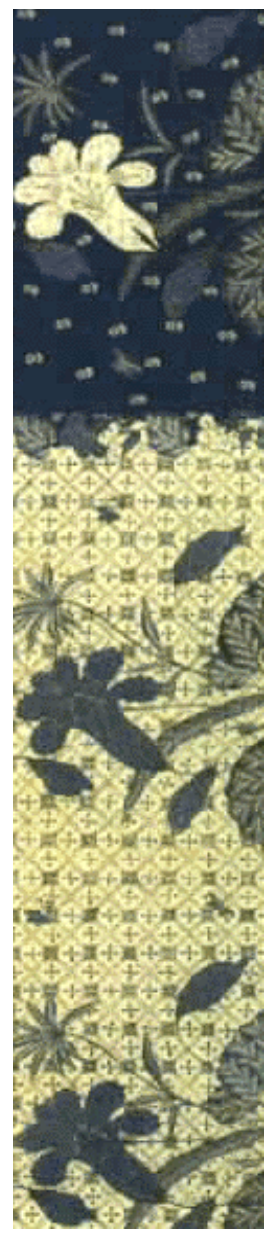

\section{INTERVENTION}

\section{Building an Informed Network of Journalists}

\section{A. Coordinating with senior editors}

A high-level round-table discussion was convened that brought together the chief editors of 21 print media agencies selected for their circulation size and interest in women's health issues. This meeting served to introduce the project to these influential individuals and provide background information on reproductive health issues. The chief editors were also invited to share their perspectives on the project activities during this meeting. The session was conducted in collaboration with the State Ministry of Women's Empowerment.

Three resource persons were selected to give presentations at this first meeting: a recognized reproductive health expert, an influential media expert, and a senior representative from the State Ministry of Women's Empowerment. In addition to the senior editors, other participants included government officials, representatives of donor agencies, collaborating agencies, local nongovernmental organizations (NGOs), and journalists.

\section{B. Developing a database of national and regional journalists}

Through an intensive networking process the project compiled a listing of all known journalists covering health-related news stories in Indonesia. The 22 most frequently mentioned print journalists working at leading newspapers, magazines, and tabloids were identified. Using these names as a starting point, other journalists were added to the listing as the project was implemented. This database was regularly updated throughout the project. Eventually, 35 journalists representing 22 publications were selected to be the core network leading the project's activities. They included health editors, senior health reporters, and junior health reporters.

\section{Training journalists}

A four-day workshop organized by project staff in collaboration with Yogya Institute of Research, Education and Publications (LP3Y) was held in Yogyakarta on January 23-27, 2000. The workshop's long-term objective was to increase and maximize media coverage of reproductive health issues. The immediate objectives were to increase the journalists' understanding and awareness of reproductive health issues and to train them to write articles 
based on scientific data. Eighteen journalists drawn from the project's core group participated in the workshop. They represented eleven newspapers, five magazines, and two tabloids.

Dr. Meiwita Budiharsana (Ford Foundation) and Professor Saparinah Sadli led the workshop sessions on reproductive health, gender perspective, and violence against women. Mr. Ashadi Siregar from LP3Y and Dr. Daniel Dhakidae from Kompas daily newspaper chaired sessions related to improving journalistic style and mastering writing techniques.

The workshop used several different methodologies for training the participants, including role-playing, simulation, testimony and field visits to practice investigation techniques followed by practice in writing short topical articles. One such field visit was to Rifka Annisa (a local NGO focusing on violence against women) and the PKBI clinic in Yogyakarta. Workshop presentations covered the definition and scope of reproductive health, gender issues, and journalistic techniques to report on such topics. A folder that contained all supporting materials, the agenda and copies of the presentations was distributed to each participant.

In addition to conducting investigations on site, the journalists were trained to collect information from other sources, to conduct interviews, and to review background documents. Each participant also was requested to write and submit a complete story, which was copied and distributed for discussion, then reviewed by the LP3Y facilitator.

\section{Media Forum Discussions}

The Media Forum Discussions (MFDs) were the primary activity of this project. These meetings provided the opportunity to present scientific data on specific topics to interested journalists and to discuss different issues of concern. The meetings also allowed the journalists to exchange views and interact with resource persons and experts in the field, thereby contributing to the development of professional associations. Topics for the five

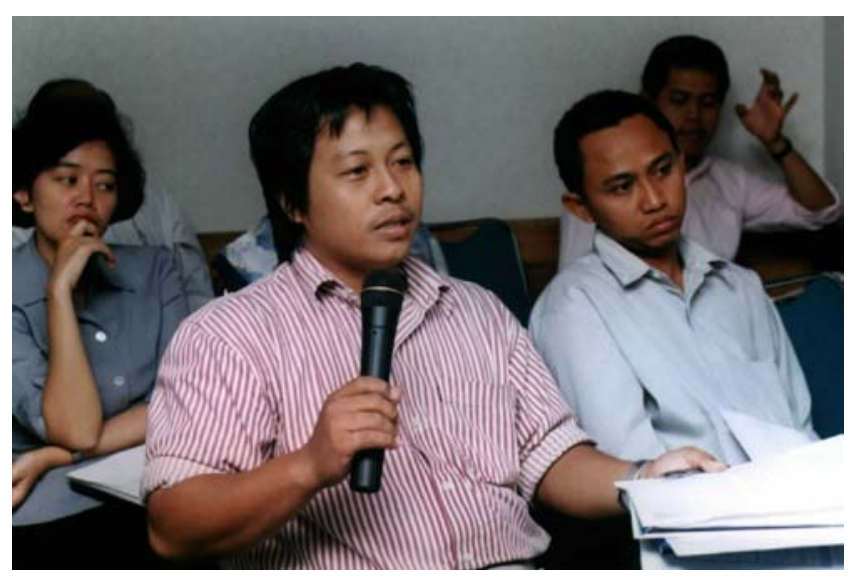
media forum discussions were identified through a broad-based consultative process.

During the early phase of the project, discussions with several stakeholders were held to finalize the list of topics. The following themes and dates were selected:

- The impact of the economic and political crisis on women's and child's health, December 22, 1999

- The impact of violence against women on reproductive health, March 1, 2000 
- $\quad$ STIs in low-risk women, May 17, 2000

- Male participation in reproductive health, July 3, 2000

- Adolescents' reproductive health, August 12, 2000

The first MFD coincided with the Indonesian Mother's Day on December 22, 1999.

This event drew journalists' attention to women's and children's health issues. Ms. Rieny Hardjono from the State Ministry of Women's Empowerment was selected as the moderator. Dr. Budi Utomo of the Population Council was the key speaker.

The final media forum discussion on adolescents' reproductive health was scheduled seven weeks before the completion of the media monitoring activities in order to permit sufficient time to assess the impact of these meetings on press coverage. During this last forum, 10 high school students were invited to provide feedback on concerns regarding reproductive health among teenagers.

In general there were two types of speakers at each of the media forum discussions: those who presented a conceptual overview and those who presented the research findings (the latter generally were Population Council staff who referred to the results of operations research studies). Representatives from the State Ministry for Women's Empowerment and other senior health journalists were also invited to participate. Two types of resource materials were produced for each media forum discussion: press briefing kits and press releases.

\section{A. Press briefing kits}

Three press kits were produced and distributed to all members of the journalists' network -- both MFD attendees and others. The three press kits covered: (1) the impact of the economic crisis on women's and children's health; (2) the impact of violence against women on reproductive health; and (3) adolescent reproductive health. Extensive background materials on reproductive health (including fact sheets) were prepared and distributed as part of the briefing kits. Each fact sheet usually contained between three and five sub-themes related to the main issue of the discussion. Both international and local data from relevant institutions were included in the fact sheets. This information was derived from studies conducted by various organizations, including USAID-funded operations research studies and the work of other agencies such as WHO. Lists of relevant resource persons and websites were included in the briefing kits.

All materials used for each kit, including the ones cited from the reproductive health database and fact sheets, were translated or summarized into Bahasa and back-translated to ensure accuracy and ease of reading. 


\section{B. Press releases}

The project developed seven press releases on topics related to the five themes of the media forums. The following five releases were timed to coincide with the five media forum discussions in order to maximize coverage:

1. Abortion in Indonesia: "An estimated 13\% of maternal deaths caused by abortion," December 22, 2000.

2. Emergency Contraceptive Pills: "A way out of unwanted pregnancy for victims of sexual violence," March 1, 2000.

3. From the North Jakarta Operations Research Study on "low-risk" women: "Although considered low-risk, housewives are at some risk of infection with STIs/RTIs," May 17, 2000.

4. Results of the explorative study on male workers and reproductive health: "Men support family planning but are reluctant to be acceptors," July 3, 2000.

5. Findings of a qualitative study on adolescents in Jakarta: "Young men are more likely than young women to initiate first time intercourse," August 12, 2000.

The other two press releases covered issues that were not based on local studies but rather on international research relevant to Indonesia. These topics were:

1. A point-and-click revolution in health and research: "New software developed by Population Council facilitates field research, available free on the Internet," April 2000.

2. "Male circumcision appears to protect men at risk of HIV infection, but cultural, medical, and ethical issues should be explored before the procedure is recommended as an intervention," June 2000.

Press releases were distributed to the journalists who formed the project core group, other journalists on the project listing, and those who sought information from project staff on an ad hoc basis.

\section{DATA COLLECTION}

A further component of the project involved assessment of the impact of training workshops and media forum discussions on actual publications. Three procedures were used for this purpose: monitoring and content analysis of publications, logging of contacts by journalists for support, and an evaluation of each event by the participants.

\section{Media Monitoring}

Project staff identified the principal outlets of national and regional newspapers, tabloids and magazines and systematically collected the publications. The collection process involved reviewing a purposive sample of leading national and regional newspapers, 
magazines, and tabloids. Table 1 shows the 22 news outlets selected, including the type of publication and circulation.

Table 1: News Outlets Selected for Monitoring

\begin{tabular}{|l|l|r|}
\hline \multicolumn{1}{|c|}{ Name of Media } & \multicolumn{1}{|c|}{ Type of Publication } & \multicolumn{1}{c|}{ Circulation } \\
\hline National Newspapers & Daily Morning & 700,000 \\
\hline Kompas & Daily Evening & 400,000 \\
\hline Suara Pembaruan & Daily Morning & 350,000 \\
\hline Media Indonesia & Daily Morning & 300,000 \\
\hline Republika & Daily Morning & 100,000 \\
\hline The Jakarta Post & Daily Morning & 100,000 \\
\hline Bisnis Indonesia & Daily Evening & 450,000 \\
\hline Regional Newspapers & Daily Morning & 261,160 \\
\hline Jawa Pos & Daily Morning & 150,000 \\
\hline Suara Merdeka & Daily Morning & 150,000 \\
\hline Pikiran Rakyat & Daily Morning & 130,000 \\
\hline Surabaya Post & Daily Morning & 75,000 \\
\hline Kedaulatan Rakyat & Weekly Magazine & 150,000 \\
\hline Solo Pos & Weekly Magazine & 100,000 \\
\hline Magazines & Weekly Magazine & 75,000 \\
\hline Gatra & Weekly Magazine & 60,000 \\
\hline Femina & Weekly Magazine & 50,000 \\
\hline Hai & Monthly Magazine & 50,000 \\
\hline Matra & Weekly Magazine & 30,000 \\
\hline Gadis & Weekly Tabloid & 300,000 \\
\hline Intisari & Weekly Tabloid & 25,000 \\
\hline Ayahbunda & Weekly Tabloid & 25,000 \\
\hline Tabloids & & \\
\hline Nova & & \\
\hline Citra & & \\
\hline Aura & & \\
\hline
\end{tabular}

For the two-month content analysis the above media sources were selected based on the following criteria:

- High circulation volume (minimum circulation of 25,000 copies);

- Broad audiences (young women, adult male, male and female teenagers, family);

- National and regional coverage; and

- Regular columns or special pages in which reproductive health news and messages were incorporated.

\section{A. Coding}

Two project staff reviewed each publication and clipped all articles on the following themes for content analysis:

- Adolescent reproductive health

- Breastfeeding

- Child health

- Family planning 
- HIV/AIDS

- Population issues in general

- RTIs/STIs

- Safe motherhood

- Violence against women

Each article was also coded by a secondary topic. Articles considered directly related to the project were those that cited information from the press materials distributed in the media forum discussions (press releases, press kits, or handouts from speakers). The following information was coded for each clipped article:

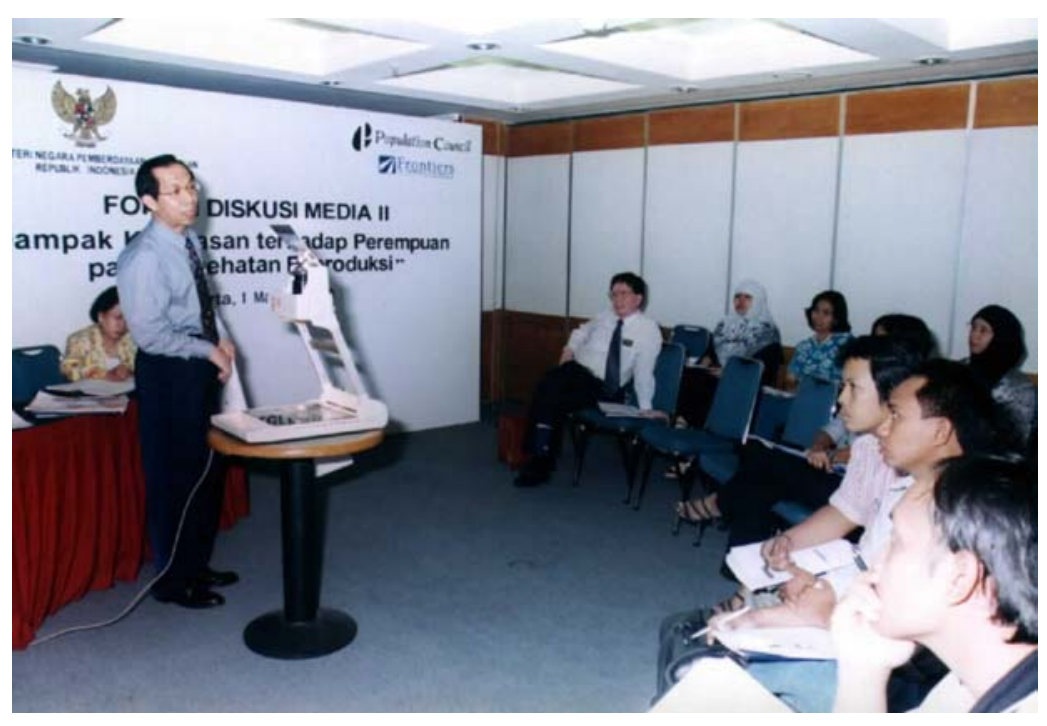

- Date of publication

- Type of publication (newspaper, magazine, tabloid, internet)

- Name of media

- Page number

- Length (in centimeters)

- Type of article (news, feature, column, letter to the editor, question and answer)

- Member of the core group of journalists (Yes/No/Unknown)

- Relevance of article: directly related to project activities, indirectly related coverage, or unrelated

- Primary content (adolescents' reproductive health, breastfeeding, child health, family planning, HIV/AIDS, Indonesian population issues, RTIs/STIs, safe motherhood, violence against women, and reproductive health in general)

- Secondary content (adolescents' reproductive health, breastfeeding, child health, family planning, HIV/AIDS, Indonesian population issues, RTIs/STIs, safe motherhood, violence against women, reproductive health in general, nutrition, and crisis impact)

All of the items recorded were then entered into a database using the Windows database program SPSS. The program helped project staff to check the frequency distribution of articles each month and quarterly, and to monitor the progress of activities.

\section{B. Content analysis report}

A content analysis of the press clippings was made quarterly beginning with the period of July-September 1999. The content analysis examined several indicators, including 
the type of publication, author, type of article (feature, editorial, news), and the primary and secondary content of the article. This analysis was presented in tables and figures and summarized in brief paragraphs. The results were routinely disseminated during the project.

\section{Journalists' Contact Sheet}

Project staff used a "Journalist Contact Sheet" to record the number of contacts made by journalists to Population Council/Jakarta seeking information about reproductive health. Information recorded on this contact sheet were: date of the call, name of the caller, category of the journalist, name of the newspaper/magazine where the journalist works, the reason for the call, and actions taken by the project staff as a result of the contact. This tool was useful in helping the staff to identify interested and committed members of the network and to improve contacts with others.

\section{Pre- and Post-Test Evaluation Sheet}

Before and after each of the media forum discussions, each journalist completed a questionnaire to provide feedback and measure the impact of the project on journalists' knowledge. The questionnaires were composed of four to five questions on information presented in the media forum discussions and five to ten multiple-choice, true/false or openended factual questions on technical material related to the theme. A similar process was undertaken before and after the training workshop to measure its impact.

\section{WRITING COMPETITION}

Near the end of the project, a writing competition was conducted to recognize the best journalist and most committed media organization for coverage of reproductive health issues. During each media forum discussion, project staff announced that all published articles on related reproductive health topics would be reviewed and the few outstanding ones selected for awards. The writing competition included all members of the core network as well as those journalists who did not directly participate in the media forums but who received project materials. Journalists were eligible for the competition if they wrote a minimum of five feature articles for newspapers or a minimum of two feature articles for magazines/tabloids on reproductive health. Articles developed on the topics of the five media forum discussion and published between December 23, 1999 and August 31, 2000 were considered. Specific criteria such as the length of the article and the layout of its design were applied differently for newspapers and magazines/tabloids. 


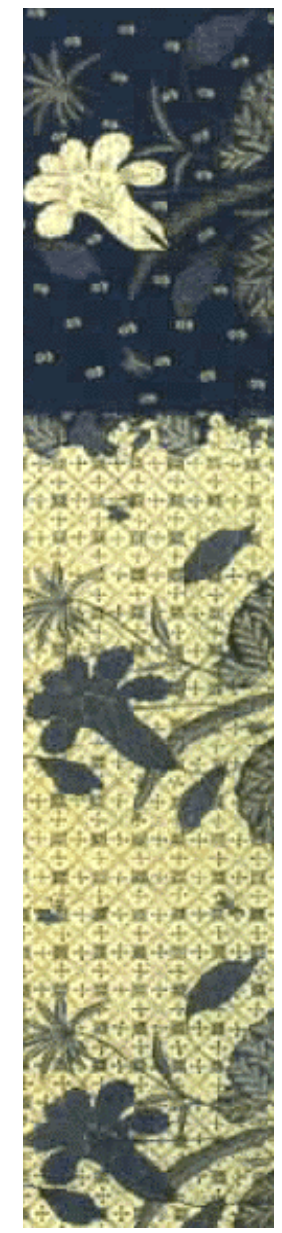

\section{FINDINGS}

\section{Impact of Training on Journalists' Reproductive Health Knowledge}

Each journalist completed a pre- and post-test questionnaire measuring his/her knowledge on reproductive health issues and the specific themes of the training workshop. The results indicated modest increases in the participants' knowledge. In the meantime, 30 news and feature articles directly related to the themes of the media forum discussions were produced by the journalists during the first three months after the training workshop. Many of these articles were based on the information provided in the briefing kit distributed in the workshop. All of the articles quoted the speakers and referred to their data and the information in the handouts. Thus the project had an immediate impact on the journalists' output of articles, in addition to improving their technical knowledge.

\section{Journalists' Contact Sheet}

Journalists telephoned project staff from up to six times monthly, with at least two contacts per month. The most common reason for the call was to seek information on relevant background literature or to identify a resource person who could be interviewed.

\section{Assessment of Media Coverage of Reproductive Health}

The monthly and quarterly review of press clippings and content analysis was the principal data source for assessing the impact of the project's activities. Figure 1 shows that during the life of the project 1,836 reproductive health articles were published in the newspapers, magazines, tabloids, and on-line media reviewed by the project. After the media forum discussions began in December 1999, the coverage of topics

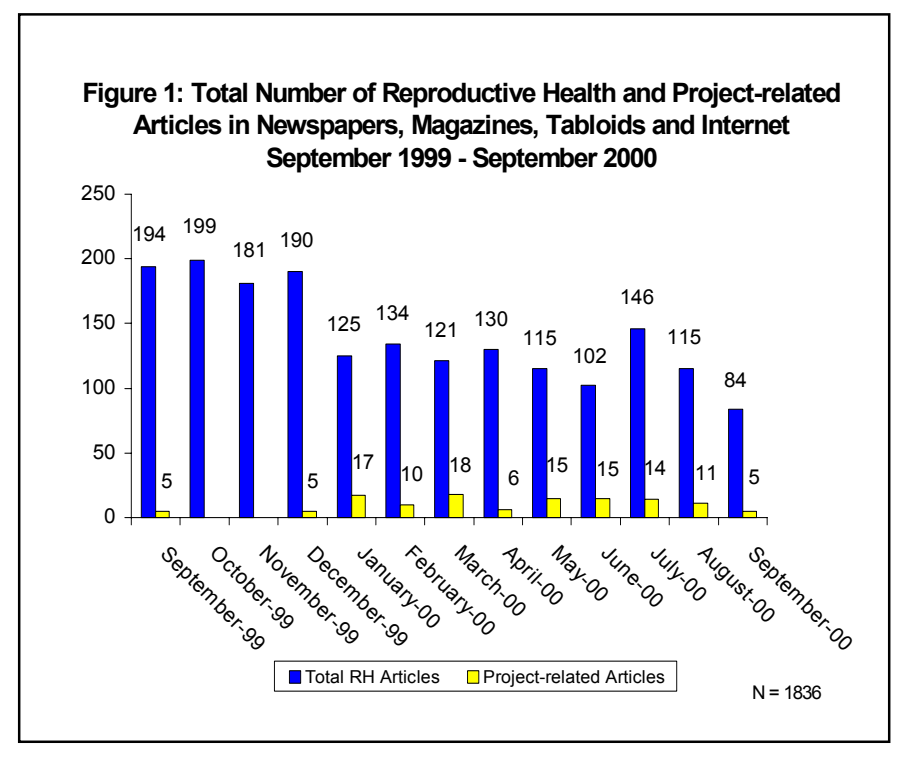
related to the project increased. In all, 120 articles on reproductive health topics directly related to the project were published between September 12, 1999 and September 30, 2000. Figure 1 shows that an average of ten articles per month were published in the sample media 
during the 13 months of media relations activities. The press releases and briefing kits distributed around each media forum had an obvious effect as the number of articles on topics related to these materials increased during the periods in which media forums were conducted.

\section{A. Newspaper coverage of reproductive health issues and project activities}

As Figure 2 shows, of the 1,473

reproductive health articles published in the sample newspapers, 56 percent were news articles, 23 percent were features, ten percent were columns, nine percent were question and answer, and one percent were letters to the editor. The higher number of news articles shows the journalists' interest in publishing

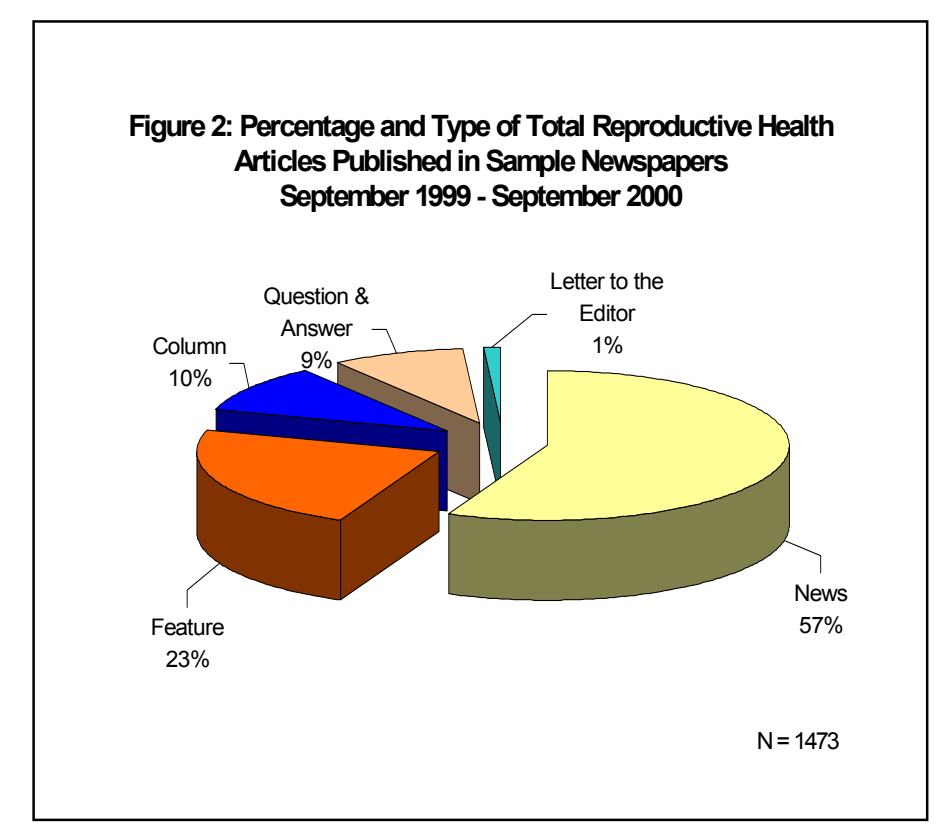
news on reproductive health. That almost a quarter of the articles take the form of features is a positive finding, since feature stories provide the space to discuss an issue in a greater length and in a more comprehensive way than a news story.

Figure 3 shows the contribution of the project intervention to the total number of reproductive health articles published in sample newspapers. On average, six newspaper articles were published every month on one of the reproductive health issues during the project period. The impact of the media forum and press briefing kits on the production of newspaper articles mirrors that of changes in the coverage of reproductive health care topics in all types of media (Figure 1). The number of newspaper

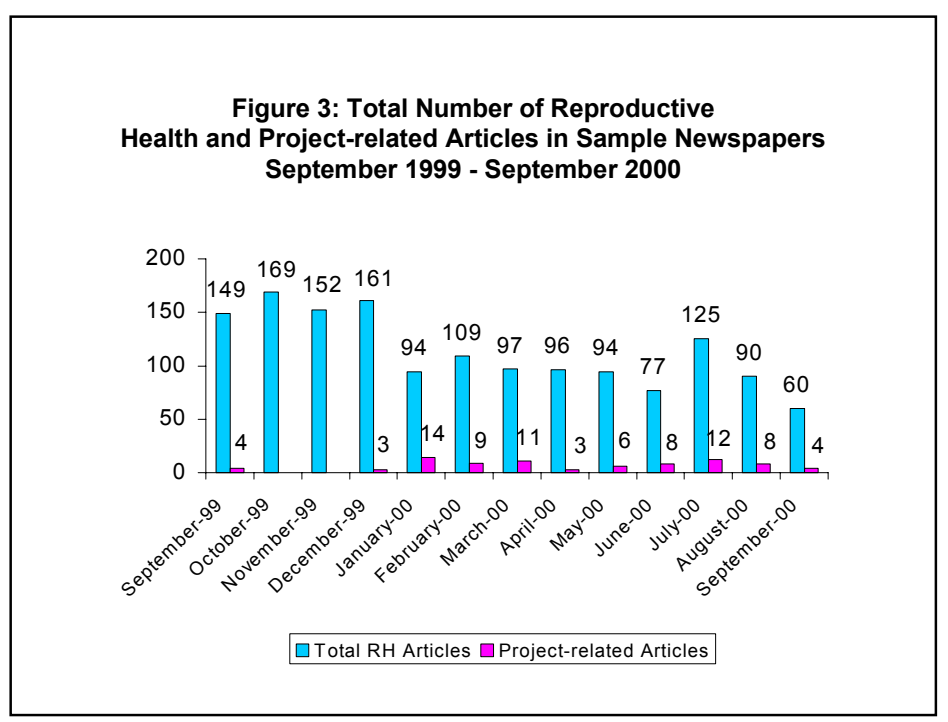
articles increased after the project activities were launched. During the 13-month mediamonitoring period, approximately 6 percent of all the newspaper articles were directly related to the topics of the project ( 82 out 1,473). 
Figure 4 shows the distribution of themes among the 82 published newspaper articles. About one in three newspaper articles were on the theme of safe motherhood, one in six were on RTIs/STIs (15 percent), 11 percent of the articles were on adolescent reproductive health, and 13 percent were on violence against women. The project materials were used by the five largest newspapers in Indonesia as well as other newspapers. Pikiran Rakyat used the project materials more often than any other newspaper (see Figure 5). Media Indonesia, with a daily circulation of 350,000 , ran the largest number of articles on reproductive health.

Meanwhile, Kompas, which has the largest circulation in Indonesia (400,000), published the second largest number of articles on reproductive health, followed by Republika.

A number of reasons determined the coverage of reproductive health and the use of the project materials. Personal interest of senior editors and health journalists was a key element. For example, the health reporter

Figure 4: Total Number of Reproductive Health and Projectrelated Articles of Different Topics in Sample Newspapers September 1999 - September 2000

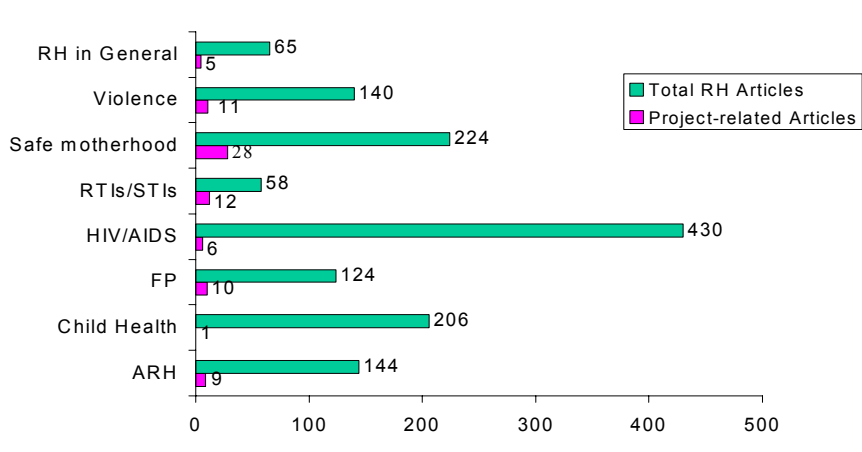
of Pikiran Rakyat, who was a member of the project network, used to frequently quote the project briefing kits in writing the stories and usually referred to the research findings included. Another important factor is having a specialized reporter who covers health and the availability of a regular designated space for presenting these issues. This explains the high coverage of reproductive health in Media Indonesia and Kompas.

\section{B. Coverage of reproductive health issues} and project activities in magazines and tabloids

Figure 6 shows the number of reproductive health and project-related articles published in magazines and tabloids.

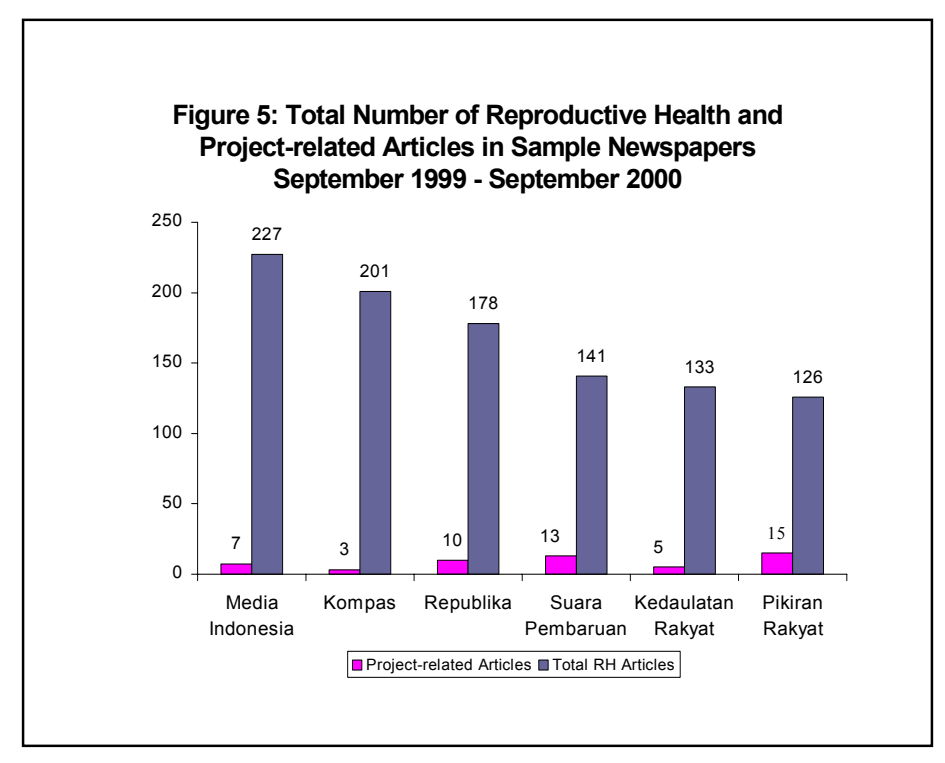
Magazines published an average of 23 articles on reproductive health monthly. Approximately 8 percent of the 344 articles in magazines and tabloids used materials or covered issues related to the project. 
Figure 7 shows that these articles were most likely to be features or question and answer. In the meantime, Figure 8 indicates that Gartra, which is a weekly magazine with a circulation of 150,000 , used project materials in about one-fifth of its articles (4 articles out of 19). Aura, a weekly tabloid, based one in four reproductive health articles (14 out of 57 articles) on the project materials.

Figure 6: Total Number of Reproductive Health and Project-related Articles in Sample Magazines and Tabloids September 1999 - September 2000
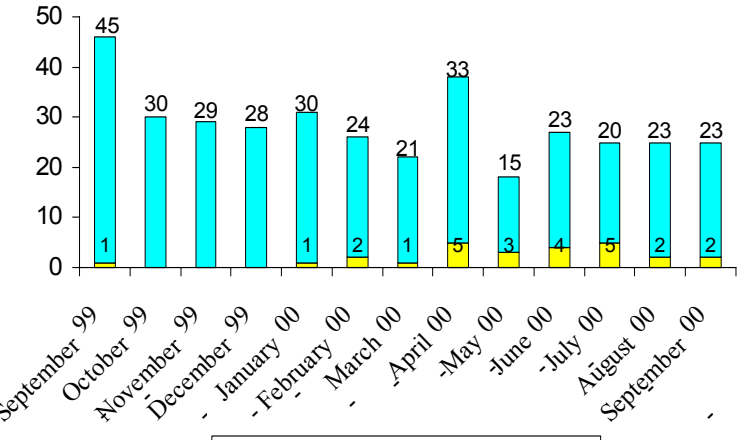

$\square$ Project-related Articles $\square$ Total RH Articles

Figure 9 shows the number of articles on reproductive health issues published in the sample magazines and tabloids that are directly attributable to the project. Similar to newspapers, safe motherhood was the most frequently covered issue in magazines, followed by HIV/AIDS. However, articles covering issues promoted by the project such as RTIs, FP and HIV/AIDS were evident in the magazine coverage. The least covered themes were breastfeeding and children's health.
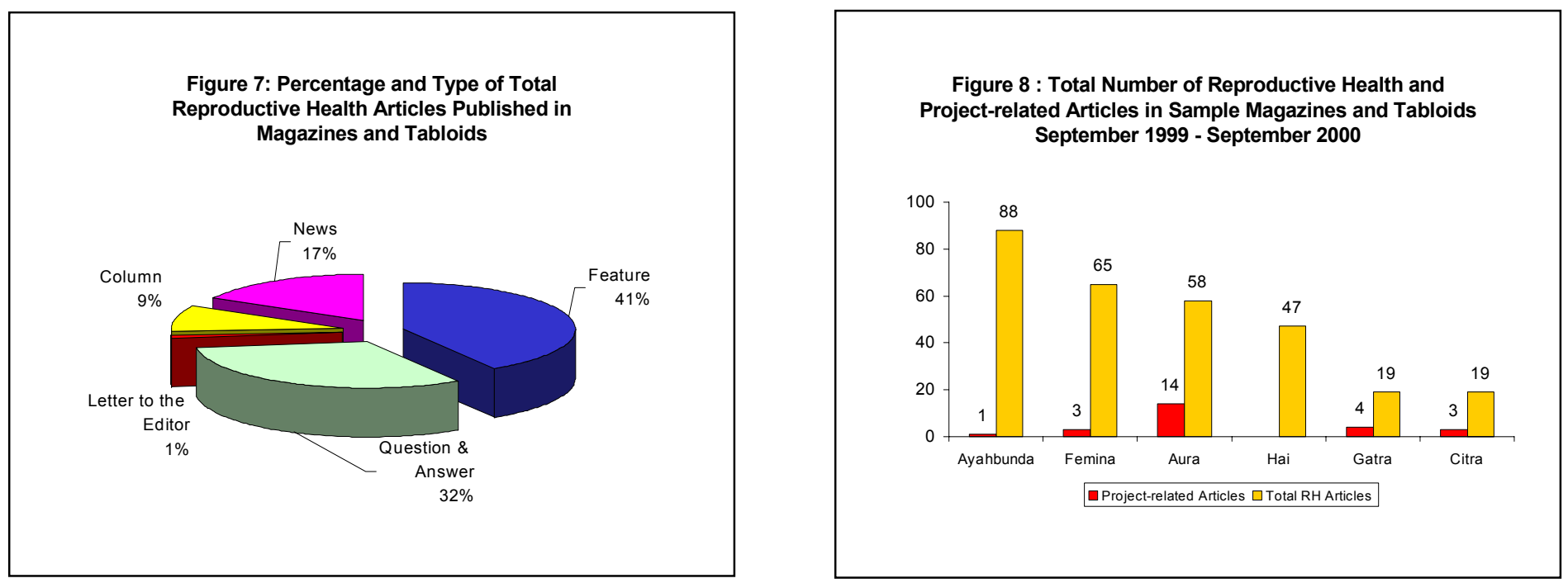


\section{Quality of media coverage}

In general, the content of articles published in newspapers and magazines addressed the media forum discussion topics or quoted statements made by the speakers. News articles most commonly incorporated some of the findings presented in the press briefing kit, while feature articles used additional information or quoted credible resource persons (government people,
Figure 9 : Total Number of Reproductive Health and Projectrelated Articles by Primary Topics in Magazines and Tabloids September 1999 - September 2000

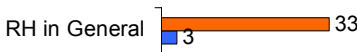

Violence 16

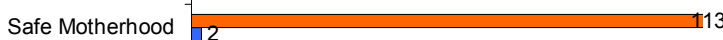

RTIs/STIs 936

HIVIAIDS 39

$\mathrm { FP } \longdiv { 5 } 2 9$

$\mathrm{ARH}$

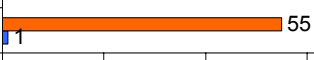

$20 \quad 40 \quad 60-80-100$

Project-related Articles $\square$ Total RH Articles activists, $\mathrm{OB} / \mathrm{GYN}$ professors) recommended by the project staff. These results demonstrate that journalists learned from the project and that the materials produced by the project were used in the Indonesian press. This section examines the quality of the articles produced by participating journalists. A sample of 120 articles on themes directly related to the project, with a minimum size of $45 \mathrm{~mm} / \mathrm{clm}$ was selected for a detailed content analysis. This sample was divided into two sets: those who attended media forum events and those who did not (group and non-group members). The evaluation criteria for the content analysis included:

- Diversity of information presented;

- Relevance of the research findings used in the article to the key topic; and

- Use of local and international research findings

The information contained in the press briefing kit was used in several articles by a range of journalists. Many of the journalists used multiple sources and completed their articles with other relevant research findings or interviewed someone from the list of recommended resource persons. One of the key elements characterizing the writing of journalists who participated in the media forums and training workshop was their objective approach in presenting the issue from different perspectives. Use of multiple sources made their stories more complete and convincing. Improved journalistic style is one of the outcomes of the project.

Almost all of the articles published in newspapers and magazines selected for content analysis incorporated results from the Population Council's operations research as one of the supporting data sources. Indeed, sometimes project topics were the main theme of the article. The vast majority of articles accurately cited the data and transferred information from the press releases without mistakes. However, a few of the articles were found to be misleading 
in terms of the relevance of the findings. Some inconsistencies and ambiguity also were observed that could lead to misinterpretation. This "risky" journalistic style suggests the need to train journalists to find the right angle for using findings.

Journalists who received the briefing kits but who had not participated in the project activities were observed to use the information of the press releases/press briefing kits directly in their articles without interpretation, elaboration or placement of results into a larger context.

\section{Impact of Reproductive Health Press Coverage on Program Management}

It is important to note that among the articles published as a result of the workshops, an interesting article was written by Republika with the title "No special attention: Women's reproductive health problems in the camp of refugees." This article cited a speech by the head of the planning bureau in the State Ministry for Women's Empowerment about the limited attention given to reproductive health needs of women refugees in the eastern part of Indonesia. The project staff contacted this official and learned that after publication of the article she was informed by another government institution that there was a change in their services to include women's sanitary napkins as one essential component, besides food, contained in the aid packages delivered to the refugee camp. This result is a positive indicator that media coverage made a difference in reproductive health programs and policies.

\section{Results of the Writing Competition}

Forty-four articles published between December 23, 1999 and August 31, 2000 were selected for the writing competition using the following criteria:

- Topic and detailed information included in the article were directly related to the project;

- The article was written by a journalist who participated in one or more project activities; and

- Feature articles were at least $45 \mathrm{~mm} / \mathrm{clm}$ for newspapers and one-half page for magazines/tabloids.

A panel of four judges reviewed the 44 articles meeting the above criteria. Dr. Budi Utomo from the Population Council/Jakarta office was the chairman of the panel. The other three members were a representative from LP3Y (as the training expert), one of the officials from the State Ministry for Women's Empowerment (representing the government), and a 
senior health journalist from the largest publishing house in Indonesia, who regularly writes high-quality reproductive health articles. Each judge received copies of the articles and a scoring sheet with a scale of 1-5 for the following five criteria:

- interesting title;

- accuracy;

- diversity of information or resources;

- relevance of utilized research to the topic of the article; and

- general ability of the writer to present the topic in an interesting and convincing way.

A final meeting of the panel was held to discuss the selection of the top three articles. The four judges conducted a final review and decided on the top three reproductive health feature articles. The judges also decided to give an award to the most comprehensive article. In addition, two articles written by journalists who did not attend media forums but whose work did use the project's materials were selected by the panel. Three newspapers and magazines also were awarded for their outstanding commitment to writing about reproductive health issues.

The results of the project and the announcement of the winners of the writing competition were released at a media event held at the end of the project. The event was attended by journalists of the project network, government staff, and NGOs. The Country Director of the Population Council and representatives from the State Ministry for Women's Empowerment gave opening speeches.

\section{CONCLUSIONS}

This 18-month media information dissemination project demonstrated several positive outcomes on the coverage of reproductive health issues in the Indonesian print media. The impact includes improving the journalists' awareness and knowledge of reproductive health and increasing the number and quality of articles. The project activities also have contributed to public debate and influenced program decisions such as the case of reproductive health in the refugee camp.

Raising the journalists' interest in reproductive health issues is a further immediate outcome. From two to six inquiries per month were received from the group members seeking further information or data. This information usually was used to write in-depth reports. Generally, the pre- and post-evaluation tests of the various projects' activities showed 
that the majority of journalists who attended the media forum discussions have improved their overall understanding of reproductive health issues.

The project activities contributed about 7 percent of the total coverage of reproductive health in newspapers, magazines and on-line articles from September 1999 through September 2000. Six percent of newspaper articles $(82 / 1,473)$ and 8 percent $(26 / 344)$ of magazine articles resulted from project activities.

Safe motherhood, RTIs/STIs, and violence against women were the most popular topics both in newspapers and magazines/ tabloids. News articles were found to be the dominant type in newspapers, while features were prevalent in magazines and tabloids. Question-and-answer articles were more common than features in magazines. This indicates a good use of an interactive style to reach out to the general public. However, capacity building programs are still needed to empower journalists to produce more investigative articles discussing reproductive health issues in greater detail.

High-circulation newspapers (such as Media Indonesia, Kompas and Republika) and magazines (such as Getra) were among the media outlets most committed to coverage of reproductive health. Thus project materials reached a large segment of the target audiences, thereby initiating public debate about these issues. The quality of articles written by both the project group and non-group members demonstrated a great diversity of information and resources and good use of research findings to substantiate key points.

\section{RECOMMENDATIONS}

The experience of conducting this project yielded the following recommendations for public and private health agencies:

- Include the results of a larger number of research studies in the process of developing press-briefing kits and media background informational materials, especially those with recent data on reproductive health issues.

- Encourage the use of reproductive health training programs for journalists as a part of all health-sector projects. Writing comprehensive stories and using research findings to support the coverage should be among key points to emphasize. Senior reproductive health journalists should be encouraged to share their experience.

- Motivate senior editors to devote more space to reproductive health issues. 
- Expand the media network to include more journalists from radio and television. Working together with radio and television media would increase the visibility of reproductive health issues, leading to a larger impact on the general public as well as program managers and policymakers. 